\title{
Evaluation of antioxidant properties of phycobiliproteins and phenolic compounds extracted from Bangia atropurpurea
}

\author{
Rajalakshmi Punampalam a, ${ }^{\text {* }}$, Kong Soo Khoo b, Nam Weng Sit c \\ a Department of Chemical Science, Faculty of Science, Universiti Tunku Abdul Rahman, 31900 Kampar, Perak, Malaysia \\ b Department of Chemical Science, Faculty of Science, Universiti Tunku Abdul Rahman, 31900 Kampar, Perak, Malaysia \\ ' Department of Biomedical Science, Faculty of Science, Universiti Tunku Abdul Rahman, 31900 Kampar, Perak, Malaysia
}

* Corresponding author: rajalakshmi@utar.edu.my

\section{Article history}

Submitted 27 Feb 2018

Revised 28 March 2018

Accepted 30 April 2018

Published online 4 June 2018

\begin{abstract}
Bangia atropurpurea is a freshwater red filamentous alga. In this study, we report on the recovery yield of purified phycobiliproteins, total phenolic content (TPC) and to evaluate their antioxidant capacity. R-phycoerythrin and R-phycocyanin were isolated by gel filtration with Sephadex G-200 and further purified by RP-HPLC. Phenolic compounds were extracted by solvents of different polarity. The Folin-Ciocalteu method was used to determine the total phenolic content (TPC), while 1, 1diphenyl-2-picrylhydrazyl (DPPH) radical scavenging and ferric reducing antioxidant power (FRAP) assays were used to measure the antioxidant activity of phycobiliproteins and phenolic compounds. $B$. atropurpurea predominantly contains R-phycoerythrin $54.80 \%$ of the total protein extracted at purity ratio $A_{562}$ to $A_{280}$ of 5.42 , while R-phycocyanin had displayed $16 \%$ yield at a purity ratio $A_{615}$ to $A_{280}$ of 3.95. The purified R-phycoerythrin exhibited better antioxidant activity $\left(I_{50}=7.66 \pm 0.81 \mu \mathrm{g} / \mathrm{mL}\right)$ and $54.81 \pm 0.31 \mathrm{mg} \mathrm{GAE} / \mathrm{g}$ extract, compared to R-phycocyanin extract and BHT for DPPH scavenging and FRAP assays, respectively. SDS-PAGE of purified R-phycoerythrin and R-phycocyanin proteins displayed a clear narrow single band with molecular weight at 20.5 and $17.6 \mathrm{kDa}$, respectively. The $100 \%$ methanol-soluble extract had the highest phenolic compounds content, $80.97 \pm 0.53 \mathrm{mg} \mathrm{GAE} / \mathrm{g}$ extract compared to phenolic content in other organic solvents used for extraction. The $100 \%$ methanol extract with highest phenolic content was evaluated with antioxidant activity assays. These assays showed that the $100 \%$ methanol extract with high phenolic content had the effective DPPH radical scavenging and ferric reduction potential $\left(\mathrm{IC}_{50}=30.82 \pm 0.92 \mu \mathrm{g} / \mathrm{mL}\right.$ extract $)$ and $37.81 \pm 0.04 \mathrm{mg}$ $\mathrm{GAE} / \mathrm{g}$ extract, respectively. $B$. atropurpurea has higher antioxidant property in positive correlation with total phenolic content however, studies have justified that the phenolic compounds were not the only contributor to the antioxidant capacities of this red alga. B. atropurpurea has abundant clusters of R-PE and R-PC, attached to the thylakoid membranes were effectively contributed to the antioxidant activities. Studies shown, the purified R-PE and R-PC exhibited better antioxidant property than phenolic compounds and synthetic antioxidant.
\end{abstract}

Keywords: Bangia atropurpurea, antioxidant, R-phycoerythrin, R-phycocyanin, phenolic compounds

\section{INTRODUCTION}

Phycobiliproteins are water-soluble pigments, forming clusters attached to the thylakoid membrane named phycobilisome. Phycobilisomes are light-harvesting apparatus of Rhodophyta division. Phycobilisomes are composed of pigmented phycobiliproteins and nonpigmented linker polypeptides. Phycobiliproteins such as phycoerythrin (PE), phycocyanin (PC) and allophycocyanin (APC) are vital to absorb light energy while, the non-pigmented linker polypeptides are important for stability and assembly of the complex (Anderson \& Grossman, 1990). The light harvesting chromophores of $\mathrm{PE}$ and PC, confer the pigments their characteristic colours, red and blue, respectively. These brilliantly coloured proteins can be divided broadly into three classes based on their spectral properties; PE ( $\lambda$ max $\sim 562 \mathrm{~nm})$, PC $(\lambda \max \sim 620 \mathrm{~nm})$ and $\mathrm{APC}(\lambda \max \sim 650 \mathrm{~nm})$ (Glazer et al., 1976).The spectral analysis was determined by measuring the wavelength at which the absorbance is greatest (McDougal \& Gamlin, 2010).

Many food industries use synthetic antioxidants to preserve food namely butylated hydroxytoluene (BHT), butylated hydroxyanisole
(BHA), propyl gallate (PG) and tert - butyl hydroquinone (TBHQ) as a food additives. Previous studies shown that the use of BHA and BHT as antioxidant could be toxic, increase manufacturing costs, lower the efficiency of natural antioxidants and increasing consumer's anxiety on food additive safety as well (Bauer, Dwyer-Nield, Hankin, Murphy, \& Malkinson, 2001; H. Witschi, Williamson, \& Lock, 1977; H. P. Witschi, 1986). Replacement of synthetic antioxidants with natural antioxidants may be beneficial due to health implications and functionality. Although, antioxidant properties of algae were proved by numerous studies from the past two decades, but least information on the antioxidant potential of Bangia atropurpurea was revealed by researchers.

Based on this background, the aim of the present study is to extract maximum phenolic compounds from Bangia atropurpurea by using different polarity solvents to identify the optimum medium for phenolic extraction. Furthermore, the correlation between the total phenolic content and the antioxidant properties were estimated. DPPH radical scavenging and FRAP assay performed to discover the antioxidant activities of the extracted phytochemicals. Phenolic compounds such as caffeic acid, chlorogenic acid, phenylpropanoids and flavonoids in 
plants of Rhodophyta division are probably responsible for the antioxidant activities (Kamali, Khosroyar, Kamali, Ahmadzadeh Sani, \& Mohammadi, 2016; Sultan, Aisa, \& Eshbakova, 2008) Concurrently, R-phycoerythrin (R-PE) and R-phycocyanin (PC) were isolated and purified from $B$. atropurpurea, and further evaluated the antioxidant capacity of these pigments to understand their beneficial value as human food or therapeutic uses. The gel filtration with Sephadex G-200 method has been applied to purify the R-PE and R-PC proteins. In addition, UV-visible absorption spectrophotometer and SDS gel electrophoresis were employed to determine the purified proteins and their molecular weights.

\section{LITERATURE REVIEW}

Free radicals and other reactive oxygen species (ROS), such as superoxide anions, hydroxyl radicals and hydrogen peroxide are highly reactive species, contribute by normal metabolism of oxygen or from exogenous factors such as smoke, chemicals, vehicles and industrial emissions (Cofrades et al., 2010). Previous studies reported that, cancer can be prevented by alga extracts, because of their antioxidant properties (Bauer et al., 2001; H. Witschi et al., 1977). Antioxidants play an important role in food preservation and human health by combating damage caused by oxidizing agents. Many phytochemical extractions possess significant antioxidant capacities that may be associated with lower incidence and lower cancer caused fatal in several populations (Velioglu, Mazza, Gao, \& Oomah, 1998).

Plants contain numerous bioactive compounds contribute to commercial use. One of the essential bioactive compound, the researchers are looking upon to extract is phenolic compounds. The antioxidant activity of phenolic compounds is mainly due to their redox properties, which can play an important role in absorbing and neutralizing free radicals, quenching singlet and triplet oxygen or decomposing peroxides. Thus, plant species with high phenolic compounds are very beneficial and in high demand.

Phycobiliproteins are pigment proteins belong to hydrophilic family, which staked together in an array to construct a complex structure called phycobilisome. The types of phycobiliproteins include red phycoerythrin, blue phycocyanin and allophycocyanin (McDougal \& Gamlin, 2010; Li Sun, Wang, Chen, \& Gong, 2003). The properties of the chromoprotein of phycoerythrin and phycocyanin have been studied since two decades ago. These studies have been revealed the aggregation of phycobiliproteins and the forces involved in the aggregation process, which expected leading to phycobilisome structure formation. Phycobilisomes are the presumed sites for phycoerythrin, phycocyanin and allophycocyanin localization in Rhodophyta division. These phycobiliproteins in algae are function as an energy-transfer pigments. The microalgae or other filamentous red algae are microscopic organisms, capable to convert solar energy to chemical energy via photosynthesis (Anderson \& Grossman, 1990). Recent studies, emphasized the potential function of algae pigments as an electron-directing agent in trans-membrane migration of electrons to against oxidative stress by metal reduction (McDougal \& Gamlin, 2010).

Hence, antioxidants can retard the oxidation process by scavenging free radicals or by acting as an electron donors ( $\mathrm{Su}$, Xie, Zhang, Zhou, \& Zhang, 2010). Natural antioxidants are able to protect from ROS and other free radicals in order, to retard the progress of many chronic diseases. In latest update, there has been a considerable increases in the occurrence of oxidative stress-related diseases as atherosclerosis, arthritis, diabetes and cancer (H. Witschi et al., 1977). After a wide range of research on methods to overcome oxidative stress-related diseases, medicinal intervention found synthetic antioxidants to solve the complication (Udegbunam et al., 2015), however due to the awareness on natural antioxidants for their potential health benefits with no or little side effects, harvesting new natural source of antioxidants became very crucial. Currently, with the higher living standards and longer life expectancy due to an advanced technology in science and economic, interest in maintaining health and youth became priority thus, at current era pharmaceutical and cosmetic industries are vastly depending on natural products.

\section{MATERIALS AND METHODS}

\section{Plant material}

The powdered Bangia atropurpurea sample bought from Algae Bioresource Centre Sdn. Bhd. The sample stored at $4{ }^{\circ} \mathrm{C}$ until further analysis.

\section{Chemicals and reagents}

All the TPC, DPPH and FRAP assays required chemicals and reagents were bought from (Merck KGaA, Germany). Sephadex G200, Bovine serum albumin (BSA), standard protein (R-PE and R-PC) were bought from (Sigma Aldrich). Coomassie brilliant blue G-250, prestained protein ladder 250-10 kDa, SDS-PAGE electrophoresis chemicals were purchased from (Bio-Rad).

\section{Extraction of phycobiliproteins}

50 grams of powdered B. atropurpurea (red alga), was added to $200 \mathrm{~mL}$ of $50 \mathrm{mM}$ phosphate buffer $(\mathrm{pH} \mathrm{7.2)}$. This mixture was sonicated under room temperature for 10 minutes to avoid denaturing of pigments. The algae slurry filtered through cheese cloths and the phycobiliprotein extraction was separated by centrifugation at 6000 rpm for 10 minutes at $4{ }^{\circ} \mathrm{C}$ (Senthilkumar et al., 2013). The procedure was repeated thrice with the pellet and the supernatant was pooled. The amounts of R-PE, R-PC and APC pigments were determined by taking the absorbance reading of supernatant at $280,562,615$ and $652 \mathrm{~nm}$, respectively.

The supernatant was precipitated with $35 \%$ saturated ammonium sulfate, $\left(\mathrm{NH}_{4}\right)_{2} \mathrm{SO}_{4}$ and the saturated mixture was centrifuged at 6000 $\mathrm{rpm}$ for 10 minutes at $4{ }^{\circ} \mathrm{C}$. The supernatant was precipitated again with $65 \%$ saturated $\left(\mathrm{NH}_{4}\right)_{2} \mathrm{SO}_{4}$ and centrifuged at $6000 \mathrm{rpm}$ for 10 minutes at $4{ }^{\circ} \mathrm{C}$. The pellet was dialyzed against $50 \mathrm{mM}$ phosphate buffer $(\mathrm{pH}$ 7.2). The precipitated phycobiliproteins was suspended in $50 \mathrm{mM}$ phosphate buffer ( $\mathrm{pH}$ 7.2) and stored at $4{ }^{\circ} \mathrm{C}$ in dark (Senthilkumar et al., 2013). The amounts of R-PE, R-PC and APC pigments were recorded again by taking the absorbance reading, respectively.

\section{Purification of R-phycoerythrin and R-phycocyanin by gel filtration and Reverse Phase-High Performance Liquid Chromatography (RP-HPLC)}

The gel filtrations with Sephadex G-200 column $(3.7 \times 65 \mathrm{~cm})$ was employed for R-PE, R-PC and APC isolations from the phycobiliprotein extracts. The gel column was equilibrated with $50 \mathrm{mM}$ phosphate buffer (pH 7.2) at $80 \mathrm{~mL} / \mathrm{h}$. Then, $5 \mathrm{~mL}$ of phycobiliprotein sample was loaded on the column. The loaded column was eluted at $60 \mathrm{~mL} / \mathrm{h}$ with the same $50 \mathrm{mM}$ phosphate buffer $(\mathrm{pH} 7.0)$ as used in the column equilibrium (L. Sun et al., 2009). The eluted fractions were collected in $3 \mathrm{~mL}$ tubes. The coloured proteins were collected in separate tubes and were monitored the absorbance reading from 190 to $800 \mathrm{~nm}$ by UV-visible spectrophotometer. The bright pinkish and purple-bluish coloured fractions collected. The protein pigments were determined based on the peak absorbance reading. The collected fraction samples were further purified by $\mathrm{C}_{18}$ column and identified the proteins accurately by RP-HPLC.

RP-HPLC separations was analysed based on absorption detection. HPLC separations on an analytical $\mathrm{C}_{18}$ column $(250 \mathrm{~mm} \times$ $4.6 \mathrm{~mm}$ ). The instrument was equipped with photodiode array (PDA) and UV-visible spectrophotometer detector. For protein separation, $10 \mu \mathrm{L}$ of R-phycoerythrin solution was injected in the column which, previously equilibrated with $75 \%$ of mobile phase A $(0.1 \%$ TFA in water) and $25 \%$ of mobile phase B (0.1\% TFA in acetonitrile). The sample and mobile phase were filtered through $0.45 \mu$ Millipore filter before injected into column to avoid blockage. The flow rate was set to be $1.0 \mathrm{~mL} / \mathrm{min}$ and in a linear gradient from $30 \%$ to $100 \%$ of B in 10 minutes (Cruz, Euerby, Johnson, \& Hackett, 1997). The PDA detector monitor the absorption of the eluent at $280 \mathrm{~nm}, 562,615$ and $652 \mathrm{~nm}$, respectively.

\section{Protein determination}

The protein content in samples were determined by Bradford assay. Bovine serum albumin, BSA was used as a standard protein for 
reference. Few dilutions of BSA protein with distilled water from range $0.1 \mathrm{mg} / \mathrm{mL}$ to $2 \mathrm{mg} / \mathrm{mL}$ were prepared. Pure distilled water kept as blank. $50 \mu \mathrm{L}$ of Bradford reagent added into each tube containing 200 $\mu \mathrm{L}$ dilutions, were incubated for 15 minutes (Bradford, 1976; Kruger, 2009). The absorbance measured at $595 \mathrm{~nm}$ with spectrophotometer and standard curve plotted. The protein content was estimated by the standard curve. The concentration of R-PE and R-PC were estimated by spectrophotometric absorption at $562 \mathrm{~nm}$ and $615 \mathrm{~nm}$, and an extinction coefficient of R-PE and R-PC, $E=1.51 \times 10^{5} \mathrm{M}^{-1} \mathrm{~cm}^{-1}$ and $E=$ $1.17 \times 10^{5} \mathrm{M}^{-1} \mathrm{~cm}^{-1}$, respectively (Rodger, 2013; Senthilkumar et al., 2013). Protein solutions were assayed in triplicate $(n=3)$.

Purity Index $=\quad \frac{\mathrm{A}_{562}}{\mathrm{~A}_{280}}$

Recovery yield $(\%)=\frac{\text { Final protein concentration }}{\text { Initial protein concentration }} \times 100 \%$

Recovery R-PE from total protein $(\%)=\frac{\text { R-PE protein }(\mathrm{mg})}{\text { Total protein }(\mathrm{mg})} \times 100 \%$

Impurities $(\%)=100-\%$ R-PE from total protein

$\mathrm{A}_{280} \mathrm{x}$ dilution conc $\mathrm{x}$ molecular weight (Daltons)

Concentration $(\mathrm{mg} / \mathrm{mL})=\frac{\mathrm{A}_{280}}{\varepsilon_{28}}$

(Rodger, 2013)

\section{Sodium dodecyl sulphate polyacrylamide electrophoresis (SDS- PAGE) analysis}

Purified R-PE and R-PC protein samples were analysed by sodium dodecyl sulphate polyacrylamide gel electrophoresis (SDS-PAGE). Electrophoresis was carried out by vertical slab gel electrophoresis (Miniprotean; Bio-rad). According to Laemmli Tris-HCl buffer system (Schneider, Newman, Sutherland, Asser, \& Greaves, 1982), the gel was composed of $16.5 \%(\mathrm{w} / \mathrm{v})$ polyacrylamide separating gel in $374.5 \mathrm{mM}$ Tris- $\mathrm{HCl}$ buffer $(\mathrm{pH} 8.8)$ containing $0.2 \%$ SDS (w/v) with a stacking gel of $5 \%(\mathrm{w} / \mathrm{v})$ polyacrylamide in $61.8 \mathrm{mM}$ Tris- $\mathrm{HCl}$ buffer $(\mathrm{pH} 6.8)$ with $0.2 \%$ SDS $(\mathrm{w} / \mathrm{v})$. Separating and stacking gels were polymerized together, by addition of $100 \mu \mathrm{L}$ of a $10 \%$ ammonium persulfate, APS solution and $10 \mu \mathrm{L}$ TEMED per $12.5 \mathrm{~mL}$. The electrode buffer was $192 \mathrm{mM}$ Tris-Glycine (pH 8.3) containing 0.1\% SDS (w/v). The R-PE and PC samples were denatured with $20 \%(\mathrm{w} / \mathrm{v})$ trichloroacetic acid, TCA and centrifuged at $4000 \times \mathrm{g}$ for 15 minutes. The protein pellet was suspended in $10 \mathrm{mM}$ phosphate buffer ( $\mathrm{pH} \mathrm{7.2)} \mathrm{with} 4 \%$ (w/v) SDS, $10 \%(\mathrm{v} / \mathrm{v})$ glycerol, $2 \%(\mathrm{v} / \mathrm{v}) \quad \beta$-mercaptoethanol, $0.025 \%(\mathrm{w} / \mathrm{v})$ bromophenol blue, incubated for 5 minutes at $95{ }^{\circ} \mathrm{C}$. The incubated suspension was centrifuged at $4000 \times \mathrm{g}$ for 15 minutes for insoluble substances to be removed. Prestained protein ladder, broad range 250 $10 \mathrm{kDa}$ (Bio-Rad) was used as molecular weight marker. After employed the electrophoresis, the slab gel was stained overnight with Coomassie brilliant blue G-250 and washed with water for 30 minutes. For calibration, marker protein was used to plot standard curve. The molecular weights of R-PE and R-PC protein were determined.

\section{Phenolic compounds extraction}

50 gram of freeze-dried sample was extracted using $200 \mathrm{~mL}$ of $100 \% \mathrm{v} / \mathrm{v}$ methanol, $50 \% \mathrm{v} / \mathrm{v}$ methanol, hexane, ethyl acetate and water. The conical flask containing slurry algae was sonicated for 10 minutes at $37{ }^{\circ} \mathrm{C}$ by ultrasonic vibration to break the cells and membranes. Then, continuously shaken on an orbital shaker for an hour before centrifuge at $2000 \times \mathrm{g}$ for 30 minutes at $4{ }^{\circ} \mathrm{C}$. The filtrate stored at $4{ }^{\circ} \mathrm{C}$ for further analysis. The same method repeated with $C$. vulgaris powder which is, well-known species for exhibiting great antioxidant property. The extracted samples were calorimetrically determined using Folin Ciocalteu method and gallic acid as standard antioxidant for reference. $1.5 \mathrm{~mL}$ Folin Ciocalteu's phenol reagent and $1.2 \mathrm{~mL}$ of $7.5 \% \mathrm{w} / \mathrm{v} \mathrm{Na}_{2} \mathrm{CO}_{3}$ were added to $0.3 \mathrm{~mL}$ sample extract. After incubated in dark for 90 minutes at room temperature, the absorbance against the prepared reagent and blank was determined at $765 \mathrm{~nm}$ (Velioglu et al., 1998). TPC was expressed in terms of mg gallic acid equivalents (GAE)/g extract and reported as mean value $\pm \mathrm{SD}(\mathrm{n}=3)$. The calibration equation for gallic acid was $y=0.0024 x \quad\left(R^{2}=0.9943\right)$.

\section{Determination of antioxidant activities (AOA)}

The $100 \%$ methanol-soluble extract which exhibited optimum phenolic content were further used in antioxidant assays. The antioxidant activities among R-PE, R-PC and methanol-soluble extract of $B$. atropurpurea were compared by perform DPPH and FRAP assays. In order to obtain more reliable results, the antioxidant property of methanol-soluble $B$. atropurpurea extract was compared with $C$. vulgaris species.

\section{1, 1-diphenyl-2-picrylhydrazyl (DPPH) radical scavenging assay}

The DPPH free radical species applied for the assessment of the radical scavenging of various antioxidant extracts. $2 \mathrm{~mL}$ of $0.15 \mathrm{mM}$ DPPH was added to the different dilutions of extracts $(1 \mathrm{~mL})$ and the reaction mixture was incubated in dark for 30 minutes at room temperature, the absorbance was measured against a blank at $517 \mathrm{~nm}$ (Rahman, Rahman, Sheik, Shadli, \& Alam, 2008). Inhibition of DPPH free radical in percentage (\%) was calculated by the formula:

$\underset{\text { Percentage }}{\text { Inhibition }(\%)}=\frac{\left(A_{\text {blank }}-A_{\text {sample }}\right)}{A_{\text {blank }}} \times 100$

Where, Ablank is the absorbance of the blank, was prepared without adding standard or test compounds and $\mathrm{A}_{\text {sample }}$ is the absorbance of the test compounds, were prepared with various dilution concentration of the samples. $\mathrm{IC}_{50}$ values (concentration of sample required to scavenge $50 \%$ of free radicals) were calculated based on regression equation. Synthetic antioxidant reagents, butylated hydroxytoluene (BHT) and ascorbic acid were used as a positive controls and all tests were carried out in triplicate $(n=3)$.

\section{Ferric- reducing antioxidant power (FRAP) assay}

FRAP assay is based on reduction of yellowish potassium ferricyanide, $\mathrm{K}_{3}\left[\mathrm{Fe}(\mathrm{CN})_{6}\right]$ to its ferrous-blue-coloured complex in the presence of antioxidants (Benzie \& Strain, 1996). The FRAP assay was determined, with appropriate modifications. A $0.1 \mathrm{M}$ potassium phosphate buffer ( $\mathrm{pH}$ 6.6) $(2.5 \mathrm{~mL})$ and $1 \% \mathrm{w} / \mathrm{v}$ potassium ferricyanide $(2.5 \mathrm{~mL})$ were mixed with various dilution extracts $(1 \mathrm{~mL})$. The reaction mixture was incubated at $50{ }^{\circ} \mathrm{C}$ for 20 minutes. After incubation, $10 \% \mathrm{w} / \mathrm{v}$ trichloroacetic acid, TCA $(2.5 \mathrm{~mL})$ was added to the mixture and centrifuged at $6000 \times \mathrm{g}$ for 10 minutes. Then, $2.5 \mathrm{~mL}$ of the supernatant was mixed with $2.5 \mathrm{~mL}$ of distilled water and $0.5 \mathrm{~mL}$ of $0.1 \%$ ferric chloride, $\mathrm{FeCl}_{3}$. The solution was incubated at room temperature for 20 minutes for colour development (Sivakumar, Prabhakar, \& Doble, 2011). The absorbance was measured at $700 \mathrm{~nm}$. A blank was prepared without adding standard or test compounds. The FRAP value was expressed in $\mathrm{mg} \mathrm{GAE/g} \mathrm{extract} \mathrm{and} \mathrm{reported} \mathrm{as} \mathrm{mean}$ value $\pm S D(n=3)$. The calibration equation for gallic acid was $y=$ $0.0017 x\left(R^{2}=0.9915\right)$. Synthetic antioxidant reagents, BHT and ascorbic acid were used as a positive controls for a comparison studies.

\section{RESULTS AND DISCUSSION}

Isolation and Purification of R-Phycoerythrin and Rphycocyanin from Bangia atropurpurea

The crude extract of phycobiliproteins were extracted from $B$. atropurpurea, which further saturated with $\left(\mathrm{NH}_{4}\right)_{2} \mathrm{SO}_{4}$ before eluted through gel filtration column containing Sephadex G-200 beads. The R-phycoerythrin (R-PE) and R-phycocyanin (R-PC) were isolated by eluting into different tubes based on colour differences. The elution samples were collected in total of \#93 tubes with an approximation of $3.0 \mathrm{~mL}$ of elution sample per tube. It was found that, those tubes with bright pink fractions (\#63 to \#71) were the fractions rich in R-PE while the tubes with purplish blue fractions (\#69 to \#79) were the fractions rich in R-PC proteins which have shown peak absorption spectrum at $562 \mathrm{~nm}$ and $615 \mathrm{~nm}$ wavelengths, respectively (Fig. 1). 


\section{Extraction and estimation of phycobiliproteins}

The phycobiliproteins found in this red alga are R-PE, R-PC and allophycocyanin (APC). The concentration of R-PE, R-PC and APC were recorded after each purification stage as shown in (Table 1). The concentration of proteins were determined by Bradford assay (Bradford, 1976; Stoscheck, 1990). The Bradford protein assay is a simple procedure to determine the total protein concentration in sample that depends upon the change in absorbance based on the proportional binding of the Coomassie dye. The protein concentration of the extraction sample is determined by comparison to that of a series of known standard protein by exhibit a linear absorbance calibration line.

Referring to Table 1 , the predominant phycobiliprotein in $B$. atropurpurea is R-PE $(0.778 \mathrm{mg} / \mathrm{g})$, recovered by liquid chromatography. The concentration of R-PC is lower than R-PE, only $0.227 \mathrm{mg} / \mathrm{g}$ was recovered while, minimum APC was recorded in the extract of the same alga species, $0.029 \mathrm{mg} / \mathrm{g}$ after saturated with $\left(\mathrm{NH}_{4}\right)_{2} \mathrm{SO}_{4}$. APC was found to be completely filtered off after gel filtration with Sephadex G-200. It has been reported by other researchers that, the phycoerythrin (PE) concentration of purified red algae namely, Portieria hornemannii, Gracilaria corticata and Gelidiella acerosa ranged from $0.39 \mathrm{mg} / \mathrm{g}$ to $1.23 \mathrm{mg} / \mathrm{g}$ of dry weight concentration while, the concentration of phycocyanin (PC) ranged from $0.18 \mathrm{mg} / \mathrm{g}$ to $0.36 \mathrm{mg} / \mathrm{g}$ of the respective species (Niu, Wang, \& Tseng, 2006). This shows that, B. atropurpurea is a species with more than average total content of R-PE and R-PC compared to other red algae species.

Table 1 The Phycobiliproteins Content in Bangia atropurpurea after Different Steps of Purification.

\begin{tabular}{lllll}
\hline & $\begin{array}{l}\text { Crude } \\
\text { extract }\end{array}$ & $\begin{array}{l}\left(\mathrm{NH}_{4}\right)_{2} \mathrm{SO}_{4} \\
\text { saturated } \\
\text { extract }\end{array}$ & $\begin{array}{l}\text { Gel } \\
\text { filtration }\end{array}$ & RP-HPLC \\
\hline $\mathrm{R}-\mathrm{PE}(\mathrm{mg} / \mathrm{g})$ & 1.569 & 1.114 & 0.934 & 0.778 \\
$\mathrm{R}-\mathrm{PC}(\mathrm{mg} / \mathrm{g})$ & 0.604 & 0.483 & 0.315 & 0.227 \\
$\mathrm{APC}(\mathrm{mg} / \mathrm{g})$ & 0.084 & 0.029 & - & - \\
\hline
\end{tabular}

The purity index of R-PE ( $\left.\mathrm{A}_{562} / \mathrm{A}_{280}\right)$ in crude extract is 0.59 only, which is lower than one $\left(\mathrm{A}_{562} / \mathrm{A}_{280}<1\right)$ (Table 2). This indicates the presence of contaminant proteins other than R-PE in the extracted sample. As a part of the purification process, the crude extract was saturated to $35 \%$ and repeated to $65 \%$ of $\left(\mathrm{NH}_{4}\right)_{2} \mathrm{SO}_{4}$ salt concentration to eliminate the remaining impurities. Gradually increasing the degree of saturation with $\left(\mathrm{NH}_{4}\right)_{2} \mathrm{SO}_{4}$, make the elimination of impurities easier and effective, as contributed to $64.8 \%$ recovery yield, with purity index of $\mathrm{A}_{562} / \mathrm{A}_{280}$ was 2.47 . The recovered sediment was dialysed and further purified by gel filtration before analysed by liquid chromatography. These techniques efficiently eliminated large amount of contaminant proteins. The fact was reflected by high absorption spectra of R-PE and $\mathrm{R}-\mathrm{PC}$ at $562 \mathrm{~nm}$ and $615 \mathrm{~nm}$ wavelengths, respectively. The purity index ratio after RP-HPLC was above 2 for R-PE and R-PC; $\mathrm{A}_{562} / \mathrm{A}_{280}$ is 5.42 and $\mathrm{A}_{615} / \mathrm{A}_{280}$ is 3.95 , respectively. The purity index above 2 are considered suitable to be used in food and cosmetic industries (Rossano, Ungaro, D'Ambrosio, Liuzzi, \& Riccio, 2003). Based on Table 2 and Table 3, the absorbance reading A562 and A615 increases with every stage of purification which are, indirectly proportional with absorbance reading of total protein at wavelength $\mathrm{A}_{280}$. This implies the purity index increases with every subsequent purification processes however, the recovery yield of R-PE obtained was not as high as reported by other researchers (Kozhummal \& D. Kaushik, 2005; Parmar, Singh, Pandey, Gnansounou, \& Madamwar, 2011). Parmar et al. (2011) reported, $80 \%$ of recovery yield of R-PE content with a purity index ratio of 1.66 for cultures from three cyanobacteria Phormidium $s p$., Lyngbya $s p$. and Halomicronema $s p$. after saturation of crude extract with $70 \%\left(\mathrm{NH}_{4}\right)_{2} \mathrm{SO}_{4}$. Whereas, (Kozhummal \& D. Kaushik, 2005 ) reported $50 \%$ of recovery yield of R-PE with $55 \%\left(\mathrm{NH}_{4}\right)_{2} \mathrm{SO}_{4}$ precipitation, with a purity index ratio of 2.89 from Nostoc muscorum species.

From the maximum absorption spectra in Fig. 1, it has been determined that phycobiliproteins extracted from $B$. atropurpurea consists of R-PE, R-PC and an insignificant amount of APC. It was noted that absence of significant absorbance reading at $652 \mathrm{~nm}$ wavelength after gel filtration, indicating APC has been eliminated from the eluted phycobiliproteins sample. APC became almost untraceable in the pooled purplish blue fractions. Most probably due to insignificant amount of APC present in B. atropurpurea species.

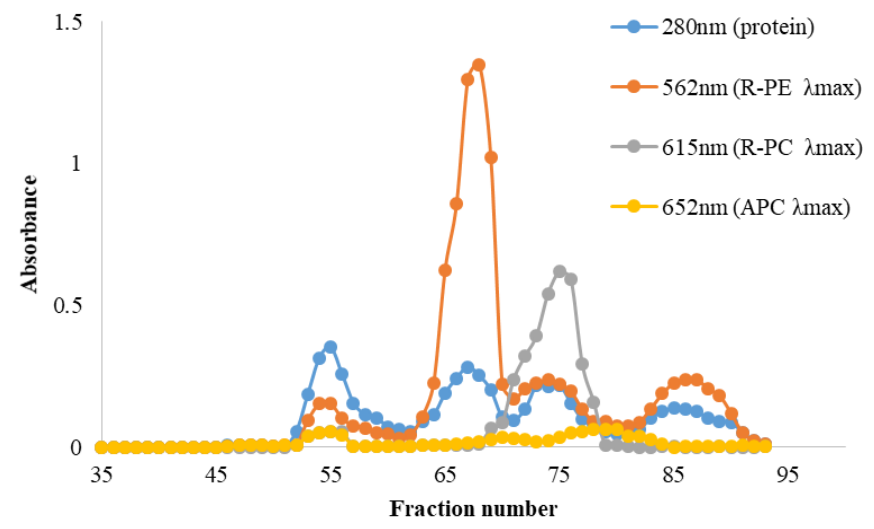

Fig. 1. Absorption spectra of isolated phycobiliproteins from Bangia atropurpurea.

Table 2 Determination of purity and recovery yield of R-phycoerythrin from Bangia atropurpurea after each steps of purification process.

\begin{tabular}{|c|c|c|c|c|}
\hline & $\begin{array}{l}\text { Crude } \\
\text { extract }\end{array}$ & $\begin{array}{l}\left(\mathrm{NH}_{4}\right)_{2} \mathrm{SO}_{4} \\
\text { saturated } \\
\text { extract }\end{array}$ & $\begin{array}{l}\text { Gel } \\
\text { filtration }\end{array}$ & RP-HPLC \\
\hline$A_{280}$ & 1.497 & 0.424 & 0.283 & 0.268 \\
\hline$A_{562}$ & 0.887 & 1.048 & 1.348 & 1.453 \\
\hline Purity Index & 0.59 & 2.47 & 4.76 & 5.42 \\
\hline \multirow{4}{*}{$\begin{array}{l}\text { Total R-PE (mg) } \\
\text { Recovery yield } \\
\text { (\%) } \\
\text { Total protein } \\
(\mathrm{mg}) \\
\mathrm{R}-\mathrm{PE} \text { from total } \\
\text { protein }(\%)\end{array}$} & 48.9 & 55.7 & 78.5 & 85.9 \\
\hline & 56.9 & 64.8 & 91.3 & 100.0 \\
\hline & 503.0 & 175.0 & 100.7 & 91.0 \\
\hline & 9.7 & 31.8 & 77.9 & 94.4 \\
\hline Impurities (\%) & 90.3 & 68.2 & 22.1 & 5.6 \\
\hline
\end{tabular}

Table 3 Determination of purity and recovery yield of phycocyanin from Bangia atropurpurea after each steps of purification process.

\begin{tabular}{lllll}
\hline & $\begin{array}{l}\text { Crude } \\
\text { extract }\end{array}$ & $\begin{array}{l}\left.\mathbf{( N H}_{4}\right)_{2} \mathbf{S O}_{4} \\
\text { saturated } \\
\text { extract }\end{array}$ & $\begin{array}{l}\text { Gel } \\
\text { filtration }\end{array}$ & $\begin{array}{l}\text { RP- } \\
\text { HPLC }\end{array}$ \\
\hline $\mathrm{A}_{280}$ & 1.497 & 0.424 & 0.220 & 0.198 \\
$\mathrm{~A}_{615}$ & 0.2 & 0.325 & 0.618 & 0.784 \\
Purity Index & 0.13 & 0.77 & 2.80 & 3.95 \\
$\begin{array}{l}\text { Total R-PC (mg) } \\
\text { Recovery yield } \\
\text { (\%) }\end{array}$ & 13.8 & 24.2 & 30.2 & 44.2 \\
$\begin{array}{l}\text { Total protein } \\
\text { (mg) }\end{array}$ & 31.3 & 54.7 & 68.3 & 100.0 \\
$\begin{array}{l}\text { R-PC from total } \\
\text { protein (\%) }\end{array}$ & 503 & 175 & 50 & 46 \\
Impurities (\%) & 2.8 & 13.8 & 60.4 & 86.1 \\
\hline
\end{tabular}

Gel filtration and RP-HPLC are proposed methods which not only focusing on the purification technique of the phycobiliproteins but also the total recovery yield of phycobiliproteins. The recovery yield increases with increase of purity index of the extracted phycobiliproteins. In this research work, the recovery yield was evaluated from the very beginning stage of extraction. At crude extraction process, only $56.9 \%$ of the R-PE was recovered (Table 2), whereas in the precipitation process with $\left(\mathrm{NH}_{4}\right)_{2} \mathrm{SO}_{4}$ salt the yield slightly hiked to $64.8 \%$. For R-phycocyanin (R-PC) the recovery yield 
increases from $31.3 \%$ to $54.7 \%$ as the purity index still lesser than 1 $\left(\mathrm{A}_{615} / \mathrm{A}_{280}<1\right)$ (Table 3). The overall recovery of the R-PE and R-PC of total extracted protein in the final purification stage were above $80 \%$. The recovery yields were slightly different for the phycobiliproteins, being higher for R-PE (94.4\% yield) and lower for R-PC (86.1\% yield). Thus, the yield at the initial stages needs to be enhanced. There are different possibilities, from optimisation of the cell disruption, extraction and precipitation conditions, to use of other methodologies such as expanded bed chromatography or ultrafiltration (Caes et al., 2013; Zaloga et al., 2015) The impurities was high at the crude extraction stage but drastically drops to lower than $6 \%$ after RP-HPLC for both R-PE and R-PC extracts. The methods implemented in the final purification stage were very effective. The gel filtration with Sephadex G-200 and RP-HPLC, contributed to higher percentage of total protein recovery yield concurrently with increase of purity index of the extracted phycobiliproteins. The purified R-PE and R-PC protein bands have been separated by polyacrylamide gel electrophoresis to justify the isolated compounds.

\section{SDS-Page}

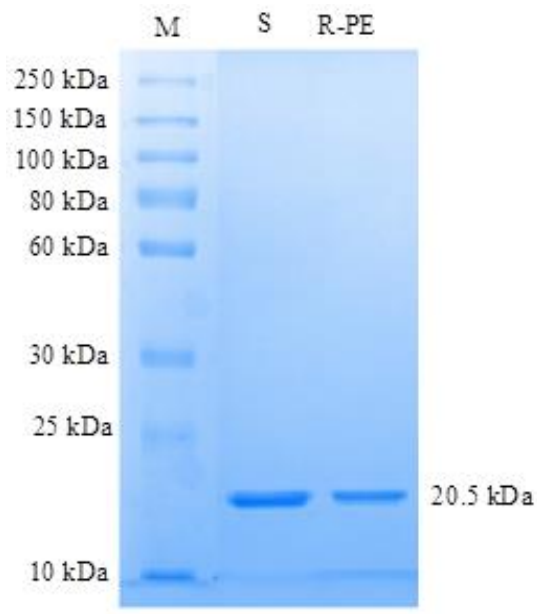

Fig. 2. SDS Gel electrophoresis of R-phycoerythrin, extracted from Bangia atropurpurea. Lane 1 (M): Prestained protein marker, broad range $(250-10 \mathrm{kDa})$; Lane 2 (S): commercial standard protein of $\mathrm{R}$ phycoerythrin; Lane 3 (R-PE): Purified sample of R-phycoerythrin.

The Fig. 2 and 3, shows the electrophoretic pattern of the gel loaded with dissociated phycobiliproteins, R-PE and R-PC. The electrophoresis gel stained by Coomassie brilliant blue G-250, reveal an apparently stained polypeptide bands parallel to commercial standard protein of R-PE and R-PC, at molecular weight $20.5 \mathrm{kDa}$ and $17.6 \mathrm{kDa}$, respectively. This indicates that the extracted phycobiliproteins are purified R-PE and R-PC. In order to obtain higher resolution of phycobiliproteins band on gel, higher percentage of polyacrylamide (PA) gel has been used. The R-PE and R-PC purified samples from B.atropurpurea were separated by SDS-PAGE on $16.5 \%$ polyacrylamide (PA) gel to obtain a clearer vision of bands under Coomassie stain instead of $12 \%$ as mentioned in other research methodology by (Bermejo Roman, Alvarez-Pez, Acien Fernandez, \& Molina Grima, 2002; Wang, Gong, Wang, Chen, \& Sun, 2014).

The gel electrophoresis process became more reliable when the protein bands appear to be more narrow and clearer after subsequent purification stage. Results showed that freshly prepared sample tends to display few vaguely formed minor polypeptide bands but according to Raps, 1990 this does not occur when the samples prepared by the same method has been frozen for several weeks before employ on gel. The absorbance wavelength of the $B$. atropurpurea exhibited "singlepeak" for R-PE with absorption maxima at $562 \mathrm{~nm}$. It presented a typical absorption spectrum of R-PE (Figure 4). UV-visible absorption spectrum of the R-phycoerythrin obtained from $B$. atropurpurea showed peak at 530-570 $\mathrm{nm}$ indicating presence of R-phycoerythrin (Figueroa et al., 2012; Gaigalas et al., 2006; L. Sun et al., 2009). Phycobiliprotein sample extracted from $B$. atropurpurea were analysed by SDS-PAGE electrophoresis. Similarly to the single peak obtained by spectrum analysis, a single band with molecular weight at $20.5 \mathrm{kDa}$ was identified by SDS-PAGE electrophoresis with bright pinkish pooled R-PE sample (Figure 3).

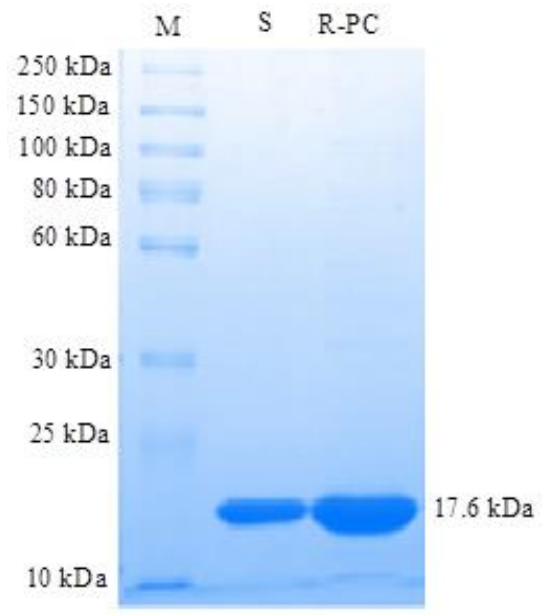

Fig. 3. SDS Gel Electrophoresis of phycocyanin, Extracted from Bangia atropurpurea. Lane $1(\mathrm{M})$ : Prestained protein marker, broad range (250$10 \mathrm{kDa}$ ); Lane $2(\mathrm{~S})$ : commercial standard protein of phycocyanin; Lane 3 (PC): Purified sample of R-phycocyanin.

The purplish blue sample was further purified by RP-HPLC was subjected to SDS gel electrophoresis. A single band was visualised at $17.6 \mathrm{kDa}$, which was suspected to be the R-PC protein (Fig. 3). The commercial standard R-PC protein band appears to be tally with the purified R-PC protein were detected on stained gel at $17.6 \mathrm{kDa}$.. The clear narrow band appeared were identified following the relative mobility $(\mathrm{Rm})$ calibration curve. As similar single peak of R-PC at maximum peak absorbance at $615 \mathrm{~nm}$ was seen in Figure 6.

The phycobiliproteins bands generally vary with their originations in molecular mass. The preparation of phycobiliproteins from marine red macroalgae by Liu and colleagues reported (Liu, Chen, Zhang, Zhang, \& Zhou, 2005), the R-PE extraction from Polysiphonia urceolate, by using a mode of ion exchange chromatography developed with a $\mathrm{pH}$ gradient on DEAE-Sepharose while, Niu and colleagues (Niu et al., 2006) reported a process prepared P. urceolata R-PE by chromatography on Q-Sepharose showed the R-PE bands to appear between 15 to $22 \mathrm{kDa}$, prepared by the both labs were consistent with my current results.

\section{Spectrophotometry}

According to light absorption properties, PEs are divided into three main types: B-phycoerythrin (B-PE; $\lambda_{\max }=565 \mathrm{~nm}, 546 \mathrm{~nm}$ and a shoulder at $499 \mathrm{~nm})$, C-phycoerythrin $\left(\mathrm{C}-\mathrm{PE} ; \lambda_{\max }=565 \mathrm{~nm}\right)$ and Rphycoerythrin (R-PE; $\lambda_{\max }=565 \mathrm{~nm}, 499 \mathrm{~nm}$ and a shoulder/peak at $545 \mathrm{~nm}$ ) (Bermejo et al., 2003; L. Sun et al., 2009). B-PE is prepared from unicellular red algae, $\mathrm{C}-\mathrm{PE}$ observed in some marine cyanobacteria while, R-PE mainly from red algae (Rhodophyta division) (Su et al., 2010).

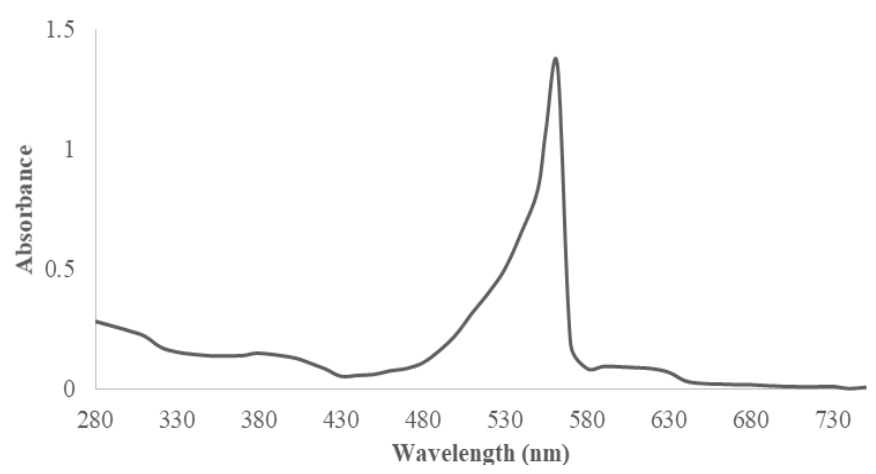

Fig. 4. Absorption spectrum of the purified R-phycoerythrin sample from Bangia atropurpurea. 
The bright pinkish fractions rich in R-PE protein were pooled after eluted by gel filtration with Sephadex G-200. The maximum absorption peak shoulder was at $540 \mathrm{~nm}$ and excited at $555 \mathrm{~nm}$. The absorption maxima was shown single peak at $562 \mathrm{~nm}$ (Fig. 4).

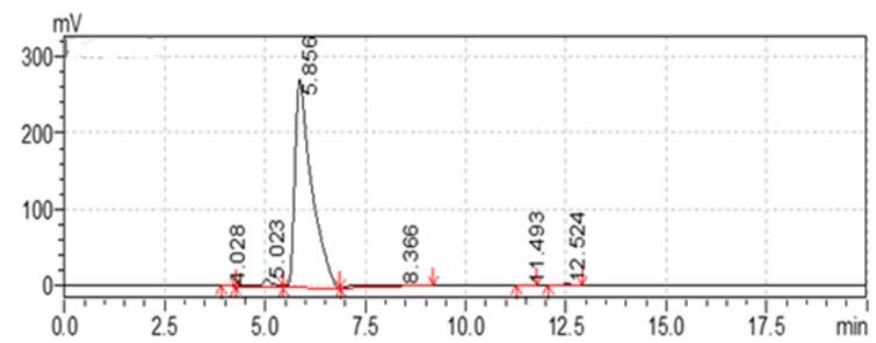

Fig. 5. Chromatogram of extracted R-phycoerythrin protein from Bangia atropurpurea, purified by gel filtration Sephadex G-200 and RP-HPLC showed retention time $5.85 \mathrm{~min}$ at $562 \mathrm{~nm}$ wavelength.

Chromatogram of Bangia atropurpurea extraction protein, saturated with $\left(\mathrm{NH}_{4}\right)_{2} \mathrm{SO}_{4}$ salt analysed by RP-HPLC showed multiple peak absorbance at $562 \mathrm{~nm}$ wavelength with retention time $4.40 \mathrm{~min}$, $5.85 \mathrm{~min}$ and $7.80 \mathrm{~min}$. The peaks of contaminant were eliminated and the remaining single peak at minute 5.85 is tally with retention time of commercial standard R-PE (Fig. 5).

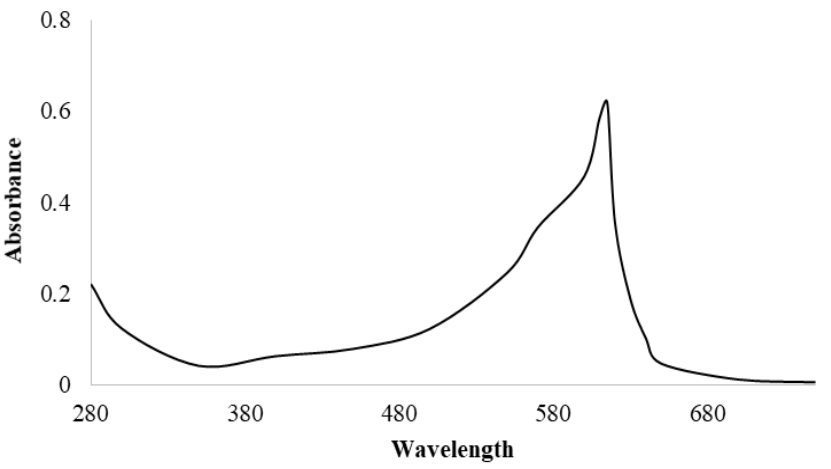

Fig. 6. The absorption spectrum of purified R-Phycocyanin extract from Bangia atropurpurea.

The purplish blue fractions rich in R-PC protein were pooled after eluted by gel filtration with Sephadex G-200. The maximum absorption peak shoulder was at $570 \mathrm{~nm}$ and excited at $610 \mathrm{~nm}$. The absorption maxima was shown in Fig. 6, a single peak at $615 \mathrm{~nm}$.

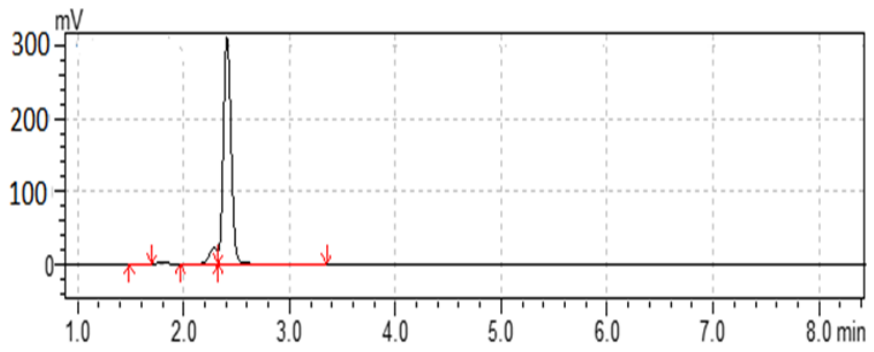

Fig. 7. Chromatogram of extracted R-phycocyanin protein from Bangia atropurpurea

Chromatogram of $B$. atropurpurea extracted protein, saturated with $\left(\mathrm{NH}_{4}\right)_{2} \mathrm{SO}_{4}$ salt analysed by RP-HPLC showed multiple peak absorbance at $615 \mathrm{~nm}$ wavelength with retention time $1.80 \mathrm{~min}, 2.50$ min and $4.30 \mathrm{~min}$. The extract further purified by gel filtration Sephadex G-200 and RP-HPLC showed retention time 2.50 min at 615 $\mathrm{nm}$ wavelength. The peaks of contaminant were eliminated and the remaining single peak at minute 2.50 minute is tally with retention time of commercial standard R-phycocyanin (Fig. 7).
Total phenolic content in Bangia atropurpurea of different extraction solvent

Table 4 Comparison of total phenolic content (TPC) extracted from Bangia atropurpurea and Chlorella vulgaris using variable extraction solvent.

\begin{tabular}{llc}
\hline & \multicolumn{2}{c}{ TPC (mg GAE/g DW) } \\
\cline { 2 - 3 } Species & \multicolumn{1}{c}{$\begin{array}{c}\text { Bangia } \\
\text { atropurpurea }\end{array}$} & $\begin{array}{c}\text { Chlorella } \\
\text { vulgaris }\end{array}$ \\
\hline $100 \%$ methanol & $80.97 \pm 0.53 \mathrm{a}$ & $62.13 \pm 1.28 \mathrm{~b}$ \\
Ethyl acetate & $61.84 \pm 0.39 \mathrm{~b}$ & $44.15 \pm 5.02 \mathrm{~d}$ \\
$50 \%$ methanol & $37.58 \pm 0.64 \mathrm{~cd}$ & $24.53 \pm 0.93 \mathrm{~h}$ \\
Hexane & $7.55 \pm 0.14 \mathrm{e}$ & $6.06 \pm 0.24 \mathrm{i}$ \\
Water & $5.21 \pm 0.03 \mathrm{e}$ & $4.37 \pm 0.04 \mathrm{ci}$ \\
\hline
\end{tabular}

Mean value $\pm S D(n=3)$, followed by different letters are significantly different at $p<0.05$ between algae species at each concentration of extract.

$100 \%$ methanol extracts exhibited the highest phenolic content followed by diethyl ether, 50\% methanol, hexane and water exhibited the least phenolic content extract solvent. Among the four organic solvents used for phenolic extraction, hexane extracts the least total phenolic content. The $100 \%$ methanol extract the highest total phenolic content as phenolic compounds are easily dissolve in polar organic solvents. The $100 \%$ methanol extraction of $B$. atropurpurea and $C$. vulgaris showed highest TPC, $80.97 \pm 0.53 \mathrm{mg}$ and $62.13 \pm 1.28 \mathrm{mg}$ $\mathrm{GAE} / \mathrm{g}$ dry weight, respectively. The minimum activity was noted in hexane and water extracts for both $B$. atropurpurea and $C$. vulgaris. The TPC reading of $B$. atropurpurea and $C$. vulgaris for hexane extract were $7.55 \pm 0.14$ and $6.06 \pm 0.24 \mathrm{mg} \mathrm{GAE} / \mathrm{g}$ dry weight, respectively (Table 4). It is found that in overall, B. atropurpurea has higher phenolic content compared to green alga $C$. vulgaris. Based on this current study and as reported by (Chakraborty, Joseph, \& Praveen, 2015; Farasat, Khavari-Nejad, Nabavi, \& Namjooyan, 2013), the red algae have higher total phenolic content as compared to the green algae species.

\section{Antioxidative activity}

\section{1, 1-diphenyl-2-picrylhydrazyl (DPPH) radical scavenging}

DPPH is a compound that possesses a nitrogen free radical and is readily destroyed by a free radical scavenger. This assay is effective to evaluate the capacity of antioxidant to inhibit radical by donating hydrogen (Singh, Dhar, \& Tabassum, 2016). The present study suggests that the methanol extraction solvent may contain phenolic compounds which having multiple - $\mathrm{OH}$ groups directly bonded to an aromatic hydrocarbon, enable them to donate a proton to DPPH radical thereby neutralizing the radicals (Ruberto, Baratta, Biondi, \& Amico, 2001). The radical scavenging effect by the extracts were concentration-dependent. The results were reported as $\mathrm{IC}_{50}$, which is defined as the amount of antioxidant required to inhibit 50\% of DPPH free radicals, this method determined lower $\mathrm{IC}_{50}$ value has higher antiradical activity.

A positive correlation was found between the TPC and $\mathrm{IC}_{50}$ reading. When TPC level was high, the $\mathrm{IC}_{50}$ value was low, indicating the increase of antioxidant property of the sample. This is due to high phenolic compounds in the sample to degrade the DPPH free radicals. The $100 \%$ methanol-soluble extracts of $B$. atropurpurea exhibited higher scavenging activity ( $\mathrm{IC}_{50}, 30.82 \pm 0.92 \mu \mathrm{g} / \mathrm{mL}$ ) compared to green algae, $C$. vulgaris species (IC50, $34.28 \pm 0.79 \mu \mathrm{g} / \mathrm{mL}$ ) (Table 5). Purified R-PE showed maximum radical scavenging with (IC 50 , $7.66 \pm 0.81 \mu \mathrm{g} / \mathrm{mL}$ ), which displayed as slightly weaker antioxidant compared to ascorbic acid (IC $50,6.78 \pm 0.28 \mu \mathrm{g} / \mathrm{mL}$ ) however, R-PE extract were shown to be better antioxidant than BHT synthetic antioxidant ( $\left.\mathrm{IC}_{50}, 35.06 \pm 1.15 \mu \mathrm{g} / \mathrm{mL}\right)$. 


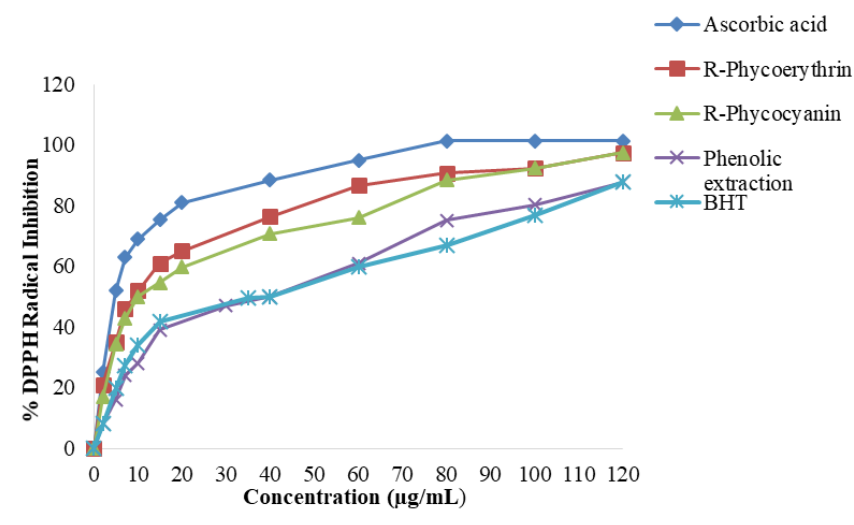

Fig. 8. Phycobiliproteins and phenolic compounds extracted from Bangia atropurpurea against DPPH radical scavenging percentage. Data are expressed as mean $\pm S D(n=3)$.

Table 5 Phycobiliproteins and phenolic compounds extracted from Bangia atropurpurea against DPPH radical scavenging percentage.

\begin{tabular}{lll}
\hline Sample & Species & $\begin{array}{l}\mathbf{5 0 \%} \text { Inhibition } \\
\text { concentration, } \mathbf{I C}_{50} \\
(\mu \mathrm{g} / \mathrm{mL} \text { extracts) }\end{array}$ \\
\hline Phenolic extracts & $\begin{array}{l}\text { Bangia } \\
\text { atropurpurea } \\
\text { Chlorella vulgaris }\end{array}$ & $30.82 \pm 0.92 \mathrm{~d}$ \\
Phenolic extracts & $\begin{array}{l}\text { Bangia } \\
\text { atropurpurea }\end{array}$ & $7.66 \pm 0.81 \mathrm{a}$ \\
R-Phycoerythrin & $\begin{array}{l}\text { Bangia } \\
\text { atropurpurea }\end{array}$ & $9.42 \pm 1.73 \mathrm{~b}$ \\
R-Phycocyanin & na & $35.06 \pm 1.15 \mathrm{e}$ \\
BHT (control) & na & $6.78 \pm 0.28 \mathrm{a}$ \\
\hline $\begin{array}{l}\text { Ascorbic acid } \\
\text { (control) }\end{array}$ &
\end{tabular}

Mean value $\pm S D,(n=3)$, followed by different letters are significantly different at $p<0.05$ according to the Tukey Kramer's post hoc test. BHT: butylated hydroxyanisole; na: Not applicable

The DPPH radical scavenging activity of R-PE extract, R-PC extract, synthetic antioxidants (ascorbic acid and BHT) and extracted phenolic compounds were evaluated and compared among one another in Fig.8. The radical scavenging activity became stable after $80 \mu \mathrm{g} / \mathrm{mL}$ concentration for both phycobiliproteins; R-PE and R-PC. There were not any drastic increment of percentage of radical scavenging activity after $80 \mu \mathrm{g} / \mathrm{mL}$ concentration for phycobiliproteins. The $50 \%$ inhibition concentration, $\mathrm{IC}_{50}$ value for R-PE and R-PC were $7.66 \pm 0.81$ and $9.42 \pm 1.73 \mu \mathrm{g} / \mathrm{mL}$, respectively. Therefore, R-PE is an effective antioxidant compared to R-PC because R-PE required lower concentration extracts to scavenge equal percentage of DPPH radical. R-PE and R-PC extract samples, displayed as a better antioxidant as compared to BHT synthetic antioxidant and phenolic compound extracts. According to DPPH assay analysis in Fig. 8, the ascorbic acid (positive control) achieved $98.87 \%$ scavenging effect at $100 \mu \mathrm{g} / \mathrm{mL}$ concentration while the R-PE and R-PC extracts achieved slightly lower scavenging effect. Phycobiliproteins achieved about $92.30 \%$ DPPH radical scavenging effect at $100 \mu \mathrm{g} / \mathrm{mL}$ concentration.

\section{Ferric reducing antioxidant power of Bangia atropurpurea extracts}

The antioxidant activity of the extracted phenolic compounds and phycobiliproteins were evaluated using reducing power assay. Reducing power were determined based on the ability of antioxidants from extracts to reduce yellowish potassium ferric cyanide, $\mathrm{Fe}^{3+}$ to blue coloured complex potassium ferrocyanide, $\mathrm{Fe}^{2+}$ (Benzie \& Strain, 1996). $\mathrm{Fe}^{3+}$ reduction is often used as an indicator of electron-donating activity, which is an antioxidant action, which can be strongly correlated with phenolic compounds ability.

Fig. 9 shows the reducing power of samples are dose-dependent, increase in absorbance at high metal reduction (Benzie \& Strain, 1996). This express that, alcoholic fraction of $B$. atropurpurea could reduce the most $\mathrm{Fe}^{3+}$ to $\mathrm{Fe}^{2+}$ ions. Total reduction capacity of the methanol extracts of $B$. atropurpurea is higher than $C$. vulgaris as recorded in
Table 6, however R-PE and R-PC extracts were exhibited more powerful reduction potential compared to overall methanolic extracts. R-PC showed an increases in inhibition as equal to R-PE at $8 \mathrm{mg} / \mathrm{mL}$ sample concentration, which was found to be $349 \pm 0.18 \mu \mathrm{g} / \mathrm{mL}$ as equivalents to gallic acid (GAE) in Fig. 9. Generally, the reducing properties are associated with the presence of phenolic compounds, exert their action by breaking the free radical chain as a result of donating a hydrogen atom or a single electron (Chojnacka \& Michalak, 2016; Cofrades et al., 2010). The reliability of the results were evaluated by comparing with two other synthetic antioxidants, ascorbic acids and Butylated hydroxytoluene (BHT). The research done was revealed, the phycobiliproteins and phenolic compounds extracted from $B$. atropurpurea, act as a better antioxidants than the synthetic antioxidant BHT however, lower reduction capacity reflected compared to ascorbic acid. The purified R-PE and R-PC exhibited better antioxidant activity, $54.81 \pm 0.31 \mathrm{mg} \mathrm{GAE} / \mathrm{g}$ DW and $42.18 \pm 0.70$, respectively. The result is significant at $p<0.05$ according to the $t$-test associate with Tukey Kramer's post hoc test.

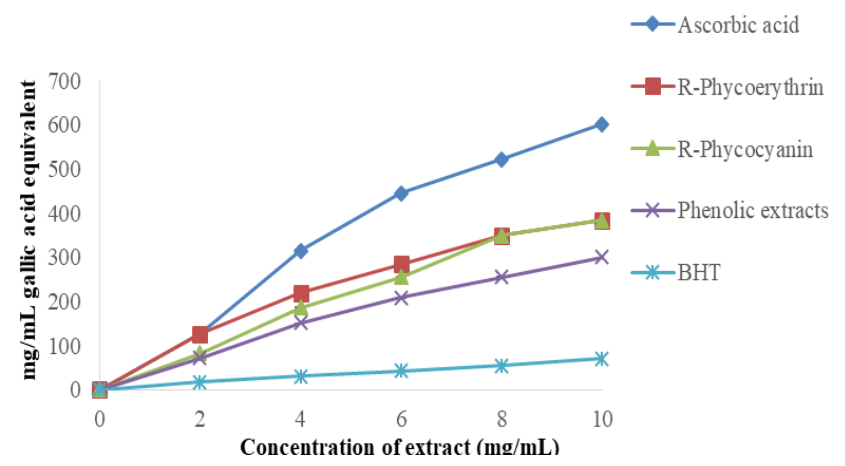

Fig. 9. Ferric reducing antioxidant power of phycobiliproteins and phenolic compounds extracted from Bangia atropurpurea.

Table 6 Ferric reducing antioxidant power by various extracts from Bangia atropurpurea and Chlorella vulgaris.

\begin{tabular}{lll}
\hline Samples & Species & $\begin{array}{l}\text { (mg gallic acid } \\
\text { equivalents (GAE)/g } \\
\text { DW) }\end{array}$ \\
\hline Phenolic extracts & $\begin{array}{l}\text { Bangia } \\
\text { atropurpurea }\end{array}$ & $37.81 \pm 0.04 \mathrm{a}$ \\
Phenolic extracts & $\begin{array}{l}\text { Chlorella vulgaris } \\
\text { Bangia }\end{array}$ & $23.97 \pm 0.61 \mathrm{~b}$ \\
R-Phycoerythrin & $\begin{array}{l}\text { atropurpurea } \\
\text { Bangia } \\
\text { atropurpurea }\end{array}$ & $54.81 \pm 0.31 \mathrm{c}$ \\
R-Phycocyanin & $42.18 \pm 0.70 \mathrm{c}$ \\
$\begin{array}{l}\text { BHT (control) } \\
\text { Ascorbic acid } \\
\text { (control) }\end{array}$ & na & $30.37 \pm 0.12 \mathrm{ab}$ \\
\hline
\end{tabular}

Mean $\pm S D,(n=3)$, followed by different letters are significantly different at $p<0.05$ according to the Tukey Kramer's post hoc test. BHT: butylated hydroxyanisole; na: Not applicable

\section{Correlation of phycobiliproteins and phenolic compounds with antioxidant activity}

Table 7. The total phenolic content (TPC) correlation with ferric reducing antioxidant power (FRAP) and DPPH radical scavenging.

\begin{tabular}{|c|c|c|c|}
\hline \multirow[b]{3}{*}{ Species } & \multirow{3}{*}{$\begin{array}{l}\text { TPC } \\
\text { (mg GAE /g } \\
\text { DW) }\end{array}$} & \multicolumn{2}{|c|}{ Antioxidant activity (AOA) } \\
\hline & & DPPH & FRAP \\
\hline & & $\mathrm{IC}_{50}(\mu \mathrm{g} / \mathrm{ml})$ & $\begin{array}{l}\text { (mg GAE /g } \\
\text { DW) }\end{array}$ \\
\hline $\begin{array}{l}\text { Bangia } \\
\text { atropurpurea }\end{array}$ & $80.97 \pm 0.53$ & $30.82 \pm 0.92$ & $37.81 \pm 0.04$ \\
\hline $\begin{array}{l}\text { Chlorella } \\
\text { vulgaris }\end{array}$ & $62.13 \pm 1.28$ & $34.28 \pm 0.79$ & $23.97 \pm 0.34$ \\
\hline
\end{tabular}

Data expressed as mean $\pm S D(n=3)$ 
In the current research done, antioxidant activities were evaluated by two different methods namely, DPPH radical scavenging and FRAP assays. The results of both methods were simplified in (Table 7). Based on the results obtained, there are significant positive correlation between total phenolic compounds and radical scavenging activity. Concluded by, higher concentration of phenolic compounds in samples, higher hydrogen binding ability by DPPH radical. In addition, high concentration of phenolic compounds, facilitate electron-donating activity of $\mathrm{Fe}^{3+}$ ion in FRAP assay. Thus, determined the total phenolic content in B. atropurpurea is higher compared to $C$. vulgaris. The TPC results were in accordance to DPPH radical scavenging activity and ferric reduction power of extracted samples from $B$. atropurpurea and C. vulgaris. Thus, the $100 \%$ methanol extract which was with higher content of phenolic compounds, exhibited stronger DPPH radical scavenging and ferric reduction activity, as reported by (Fu, Luo, \& Zhang, 2009; Li et al., 2007) in their previous studies.

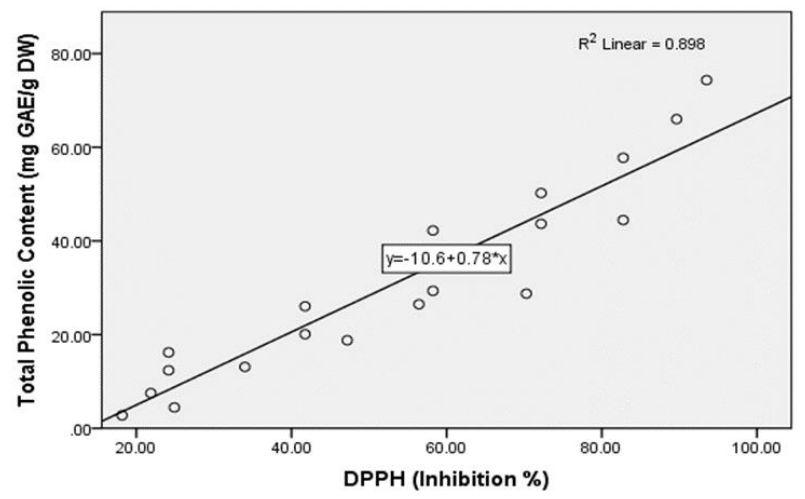

Fig. 10. Correlation studies between total phenolic content (TPC) and antioxidant activities by DPPH radical inhibition. The statistical analysis (SPSS 21) indicates positive and highly significant $(p<0.001)$ relationship between total phenolic content and antioxidant activity. $R^{2}=$ $0.898, \mathrm{y}=-10.6+0.78 x, \mathrm{n}=15$.

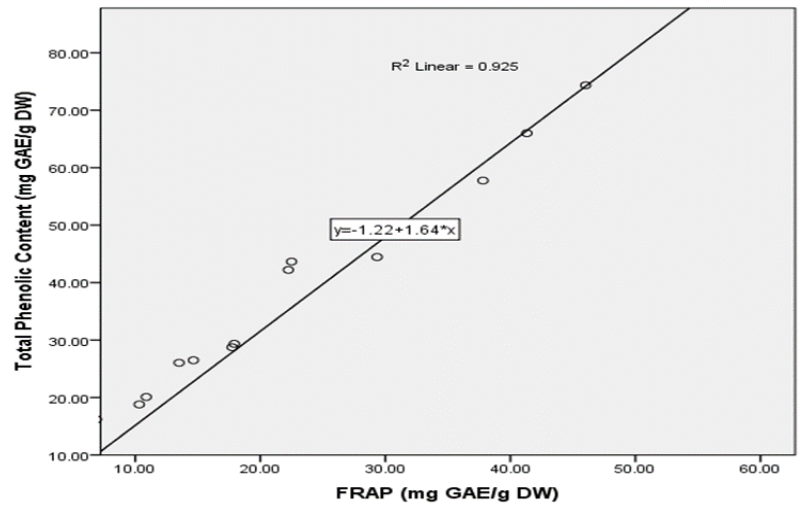

Fig. 11. Correlation studies between total phenolic content (TPC) and antioxidant activities by ferric reducing antioxidant power (FRAP). The statistical analysis (SPSS 21) indicates positive and highly significant $(p<0.001)$ relationship between total phenolic content and antioxidant activity. $\mathrm{R}^{2}=0.925, \mathrm{y}=-1.22+1.64 x, \mathrm{n}=15$.

A positive relationship were observed between phenolic content and antioxidant activity based on FRAP and DPPH radical scavenging assays (Fig. 10 and Fig. 11). The total phenolic compounds extracted from Bangia atropurpurea and Chlorella vulgaris were depended on variable extraction solvent used. B. atropurpurea contain higher phenolic compounds compared to $C$. vulgaris thus, $B$. atropurpurea able to exhibit greater antioxidant activity.

B. atropurpurea has higher antioxidant property in positive correlation with total phenolic content however, studies have justified that the phenolic compounds were not the only contributor to the antioxidant capacities of this red alga. B. atropurpurea has abundant clusters of R-PE and R-PC, attached to the thylakoid membranes were effectively contributed to the antioxidant activities. Studies shown, the purified R-PE and R-PC exhibited better antioxidant property than phenolic compounds. In compliance with an earlier report by (ElMaarouf-Bouteau, Meimoun, Job, Job, \& Bailly, 2013; Nagai, Imai, Matsushige, \& Fukushima, 2007), an introduction to the bio-regulatory functions of the phycobiliprotein in quenching various active oxygen species. Further purification and isolation of phycobiliproteins from $B$. atropurpurea extracts were done to survey, the types and the predominant phycobiliprotein which has contributed in free radical scavenging and metal reduction properties. Previously reported literature by Hesam and colleagues (Hesam, Balali, \& Tehrani, 2012), indicated phycobiliproteins has the antioxidative activity equal to synthetic antioxidant and better than phenolic compounds.

\section{CONCLUSION}

The present study showed $B$. atropurpurea is a red alga with predominant R-PE which contribute better antioxidative activity than synthetic antioxidant. In addition, presence of R-PC and phenolic compounds in $B$. atropurpurea enhance the antioxidant activity. The findings of this study support, $B$. atropurpurea could be a promising new source of potential antioxidant to be used as a preventive agents against various oxidative stress-related diseases. In addition, to replace synthetic antioxidants and nutritional supplements.

Research in natural products of algae has made significant advances in recent years. The use of phycobiliproteins as non-toxic and non-carcinogenic natural food colourants is gaining importance worldwide in view of the potential toxicity and carcinogenicity of the synthetic food colourants (Prozyme, 1999, Spolaore et al., 2006, Raja et al., 2008). Natural products are gaining importance as safe and effective alternative to synthetic chemicals.

\section{ACKNOWLEDGEMENT}

This study is supported by UTAR Research Fund, Project number (IPSR/RMC/UTARRF/C2-11/R02), funded by Universiti Tunku Abdul Rahman.

\section{REFERENCES}

Anderson, L. K., \& Grossman, A. R. (1990). Structure and light-regulated expression of phycoerythrin genes in wild-type and phycobilisome assembly mutants of Synechocystis sp. strain PCC 6701. Journal of Bacteriology, 172(3), 1297-1305.

Bauer, A. K., Dwyer-Nield, L. D., Hankin, J. A., Murphy, R. C., \& Malkinson, A. M. (2001). The lung tumor promoter, butylated hydroxytoluene (BHT), causes chronic inflammation in promotion-sensitive BALB/cByJ mice but not in promotion-resistant CXB4 mice. Toxicology, 169(1), 1-15.

Benzie, I. F., \& Strain, J. J. (1996). The ferric reducing ability of plasma (FRAP) as a measure of "antioxidant power": the FRAP assay. Anal Biochem, 239(1), 70-76.

Bermejo, R., Acien, F. G., Ibanez, M. J., Fernandez, J. M., Molina, E., \& Alvarez-Pez, J. M. (2003). Preparative purification of B-phycoerythrin from the microalga Porphyridium cruentum by expanded-bed adsorption chromatography. J Chromatogr B Analyt Technol Biomed Life Sci, 790(12), 317-325

Bermejo Roman, R., Alvarez-Pez, J. M., Acien Fernandez, F. G., \& Molina Grima, E. (2002). Recovery of pure B-phycoerythrin from the microalga Porphyridium cruentum. J Biotechnol, 93(1), 73-85.

Bradford, M. M. (1976). A rapid and sensitive method for the quantitation of microgram quantities of protein utilizing the principle of protein-dye binding. Anal Biochem, 72(1), 248-254.

Caes, B. R., Van Oosbree, T. R., Lu, F., Ralph, J., Maravelias, C. T., \& Raines, R. T. (2013). Simulated Moving Bed Chromatography: Separation and Recovery of Sugars and Ionic Liquid from Biomass Hydrolysates. ChemSusChem, 6(11), 2083-2089. doi:10.1002/cssc.201300267

Chakraborty, K., Joseph, D., \& Praveen, N. K. (2015). Antioxidant activities and phenolic contents of three red seaweeds (Division: Rhodophyta) harvested from the Gulf of Mannar of Peninsular India. Journal of Food Science and Technology, 52(4), 1924-1935. doi:10.1007/s13197-013-1189-2

Chojnacka, K., \& Michalak, I. (2016). Marine Nutraceuticals. In Marine OMICS: Principles and Applications (pp. 327-345): CRC Press. 
Cofrades, S., López-Lopez, I., Bravo, L., Ruiz-Capillas, C., Bastida, S., Larrea, M. T., \& Jiménez-Colmenero, F. (2010). Nutritional and Antioxidant Properties of Different Brown and Red Spanish Edible Seaweeds. Revista de Agaroquimica y Tecnologia de Alimentos, 16(5), 361-370. doi:doi:10.1177/1082013210367049

Cruz, E., Euerby, M. R., Johnson, C. M., \& Hackett, C. A. (1997). Chromatographic classification of commercially available reverse-phase HPLC columns. Chromatographia, 44(3), 151-161. doi:10.1007/BF02466449

El-Maarouf-Bouteau, H., Meimoun, P., Job, C., Job, D., \& Bailly, C. (2013). Role of protein and mRNA oxidation in seed dormancy and germination. Frontiers in Plant Science, 4, 77. doi:10.3389/fpls.2013.00077

Farasat, M., Khavari-Nejad, R. A., Nabavi, S. M., \& Namjooyan, F. (2013). Antioxidant Properties of two Edible Green Seaweeds From Northern Coasts of the Persian Gulf. Jundishapur J Nat Pharm Prod, 8(1), 47-52.

Figueroa, M., Martínez-Oyanedel, J., Matamala, A. R., Dagnino-Leone, J., Mella, C., Fritz, R., . . . Bunster, M. (2012). In silico model of an antenna of a phycobilisome and energy transfer rates determination by theoretical Förster approach. Protein Science : A Publication of the Protein Society, 21(12), 1921-1928. doi:10.1002/pro.2176

Fu, H., Luo, Y., \& Zhang, D. (2009). [Studies on chemical constituents of leaves of Psidium guajava]. Zhongguo Zhong Yao Za Zhi, 34(5), 577-579.

Gaigalas, A., Gallagher, T., Cole, K. D., Singh, T., Wang, L., \& Zhang, Y. Z. (2006). A multistate model for the fluorescence response of $\mathrm{R}$ phycoerythrin. Photochem Photobiol, 82(3), 635-644. doi:10.1562/200505-26-ra-544

Glazer, A. N., Apell, G. S., Hixson, C. S., Bryant, D. A., Rimon, S., \& Brown, D. M. (1976). Biliproteins of cyanobacteria and Rhodophyta: Homologous family of photosynthetic accessory pigments. Proceedings of the National Academy of Sciences, 73(2), 428-431.

Hesam, F., Balali, G. R., \& Tehrani, R. T. (2012). Evaluation of antioxidant activity of three common potato (Solanum tuberosum) cultivars in Iran. Avicenna Journal of Phytomedicine, 2(2), 79-85.

Kamali, M., Khosroyar, S., Kamali, H., Ahmadzadeh Sani, T., \& Mohammadi, A. (2016). Phytochemical screening and evaluation of antioxidant activities of Dracocephalum kotschyi and determination of its luteolin content. Avicenna Journal of Phytomedicine, 6(4), 425-433.

Kozhummal, R., \& D. Kaushik, B. (2005). Purification of phycobiliproteins from Nostoc muscorum (Vol. 64), 372-375.

Kruger, N. J. (2009). The Bradford method for protein quantitation. The protein protocols handbook, 17-24.

Li, H.-B., Cheng, K.-W., Wong, C.-C., Fan, K.-W., Chen, F., \& Jiang, Y. (2007). Evaluation of antioxidant capacity and total phenolic content of different fractions of selected microalgae. Food chemistry, 102(3), 771-776.

Liu, L.-N., Chen, X.-L., Zhang, X.-Y., Zhang, Y.-Z., \& Zhou, B.-C. (2005). One-step chromatography method for efficient separation and purification of R-phycoerythrin from Polysiphonia urceolata. J Biotechnol, 116(1), 91100 .

McDougal, D. H., \& Gamlin, P. D. (2010). The influence of intrinsicallyphotosensitive retinal ganglion cells on the spectral sensitivity and response dynamics of the human pupillary light reflex. Vision research, $50(1), 72-87$.

Nagai, T., Imai, A., Matsushige, K., \& Fukushima, T. (2007). Growth characteristics and growth modeling of Microcystis aeruginosa and Planktothrix agardhii under iron limitation. Limnology, 8(3), 261-270. doi:10.1007/s10201-007-0217-1

Niu, J. F., Wang, G. C., \& Tseng, C. K. (2006). Method for large-scale isolation and purification of R-phycoerythrin from red alga Polysiphonia urceolata Grev. Protein Expr Purif, 49(1), 23-31. doi:10.1016/j.pep.2006.02.001

Parmar, A., Singh, N. K., Pandey, A., Gnansounou, E., \& Madamwar, D. (2011). Cyanobacteria and microalgae: a positive prospect for biofuels. Bioresour Technol, 102(22), 10163-10172. doi:10.1016/j.biortech.2011.08.030

Rahman, A., Rahman, M. M., Sheik, M., Shadli, S., \& Alam, M. (2008). Free radical scavenging activity and phenolic content of Cassia sophera $\mathrm{L}$. African Journal of Biotechnology, 7(10), 20-28.
Rodger, A. (2013). Concentration Determination Using Beer-Lambert Law. In G. C. K. Roberts (Ed.), Encyclopedia of Biophysics (pp. 360-361). Berlin, Heidelberg: Springer Berlin Heidelberg.

Rossano, R., Ungaro, N., D'Ambrosio, A., Liuzzi, G. M., \& Riccio, P. (2003). Extracting and purifying R-phycoerythrin from Mediterranean red algae Corallina elongata Ellis \& Solander. J Biotechnol, 101(3), 289-293.

Ruberto, G., Baratta, M. T., Biondi, D. M., \& Amico, V. (2001). Antioxidant activity of extracts of the marine algal genus Cystoseira in a micellar model system. Journal of Applied Phycology, 13(5), 403-407. doi:10.1023/a:1011972230477

Schneider, C., Newman, R. A., Sutherland, D. R., Asser, U., \& Greaves, M. F. (1982). A one-step purification of membrane proteins using a high efficiency immunomatrix. Journal of Biological Chemistry, 257(18), 10766-10769.

Senthilkumar, N., Suresh, V., Thangam, R., Kurinjimalar, C., Kavitha, G., Murugan, P., . . Rengasamy, R. (2013). Isolation and characterization of macromolecular protein R-Phycoerythrin from Portieria hornemannii. International journal of biological macromolecules, 55, 150-160.

Singh, N. K., Dhar, D. W., \& Tabassum, R. (2016). Role of Cyanobacteria in Crop Protection. Proceedings of the National Academy of Sciences, India Section B: Biological Sciences, 86(1), 1-8.

Sivakumar, P., Prabhakar, P., \& Doble, M. (2011). Synthesis, antioxidant evaluation, and quantitative structure-activity relationship studies of chalcones. Medicinal Chemistry Research, 20(4), 482-492.

Stoscheck, C. M. (1990). Quantitation of protein. Methods Enzymol, 182, 50-68.

Su, H. N., Xie, B. B., Zhang, X. Y., Zhou, B. C., \& Zhang, Y. Z. (2010). The supramolecular architecture, function, and regulation of thylakoid membranes in red algae: an overview. Photosynth Res, 106(1-2), 73-87. doi:10.1007/s11120-010-9560-x

Sultan, A., Aisa, H., \& Eshbakova, K. (2008). Flavonoids from Dracocephalum moldavica. Chemistry of Natural Compounds, 44(3), 366-367.

Sun, L., Wang, S., Chen, L., \& Gong, X. (2003). Promising fluorescent probes from phycobiliproteins. IEEE Journal of selected topics in quantum electronics, 9(2), 177-188.

Sun, L., Wang, S., Gong, X., Zhao, M., Fu, X., \& Wang, L. (2009). Isolation, purification and characteristics of R-phycoerythrin from a marine macroalga Heterosiphonia japonica. Protein Expr Purif, 64(2), 146-154. doi:10.1016/j.pep.2008.09.013

Udegbunam, S. O., Udegbunam, R. I., Nnaji, T. O., Anyanwu, M. U., Kene, R. O. C., \& Anika, S. M. (2015). Antimicrobial and antioxidant effect of methanolic Crinum jagus bulb extract in wound healing. Journal of Intercultural Ethnopharmacology, 4(3), 239.

Velioglu, Y. S., Mazza, G., Gao, L., \& Oomah, B. D. (1998). Antioxidant Activity and Total Phenolics in Selected Fruits, Vegetables, and Grain Products. Journal of Agricultural and Food Chemistry, 46(10), 4113-4117. doi:10.1021/jf9801973

Wang, Y., Gong, X., Wang, S., Chen, L., \& Sun, L. (2014). Separation of native allophycocyanin and R-phycocyanin from marine red macroalga Polysiphonia urceolata by the polyacrylamide gel electrophoresis performed in novel buffer systems. PLoS One, 9(8), e106369. doi:10.1371/journal.pone.0106369

Witschi, H., Williamson, D., \& Lock, S. (1977). Enhancement of urethan tumorigenesis in mouse lung by butylated hydroxytoluene. J Natl Cancer Inst, 58(2), 301-305.

Witschi, H. P. (1986). Enhanced tumour development by butylated hydroxytoluene (BHT) in the liver, lung and gastro-intestinal tract. Food Chem Toxicol, 24(10-11), 1127-1130.

Zaloga, J., Stapf, M., Nowak, J., Pöttler, M., Friedrich, R. P., Tietze, R., . . . Alexiou, C. (2015). Tangential Flow Ultrafiltration Allows Purification and Concentration of Lauric Acid-/Albumin-Coated Particles for Improved Magnetic Treatment. International Journal of Molecular Sciences, 16(8), 19291-19307. doi:10.3390/ijms160819291. 